\title{
EFFECTS OF TEMPERATURE AND PRE-GERMINATIVE TREATMENTS ON SEED GERMINATION OF Talinum triangulare (Jacq.) Willd (PORTULACACEAE) ${ }^{1}$
}

\author{
BEATRIZ GONÇALVES BRASILEIRO²; DENISE CUNHA F. S. DIAS ${ }^{3}$; VICENTE WAGNER DIAS CASALI; \\ MARIA CARMEN BHERING5; PAULO ROBERTO CECON ${ }^{6}$
}

\begin{abstract}
The objective of this study was to evaluate the effects of temperature, substrate and pre-germinative treatments on T. triangulare seeds. Four temperatures (constant 20, $25,30{ }^{\circ} \mathrm{C}$ and alternate $20-30{ }^{\circ} \mathrm{C}$ ) and two types of seeding (on paper and between paper), with light, were evaluated. The pre-germinative treatments evaluated included: immersion in water (24 hours), immersion in 6\% hypochlorite solution ( 1 hour), immersion in $0.2 \%$ potassium nitrate solution ( 24 hours), immersion in $0.05 \%$ gibberellin solution ( 24 hours) and the control (untreated seeds). The highest germination percentage was observed at the alternate temperatures of $20-30{ }^{\circ} \mathrm{C}$, but with no significant difference between the substrates at this temperature. Soaking seeds in $\mathrm{KNO}_{3}$ gave the highest percentage germination and germination speed index (GSI), which differed from the other treatments except for soaking in water. Presoaking of $T$. triangulare seeds favors germination and may be done only in pure water, resulting in a more rapid and uniform germination.
\end{abstract}

Index terms: substrate, germination, dormancy, medicinal plant.

\section{TEMPERATURA E TRATAMENTOS PRÉ-GERMINATIVOS NA GERMINAÇÃO DE SEMENTES DE Talinum triangulare (Jacq.) Willd (PORTULACACEAE)}

\begin{abstract}
RESUMO - O objetivo neste trabalho foi avaliar os efeitos da temperatura, substrato e tratamentos pré-germinativos, sobre a germinação das sementes de T. triangulare. Foram avaliadas quatro temperaturas (constantes de 20, 25, $30{ }^{\circ} \mathrm{C}$ e alternada de $20-30{ }^{\circ} \mathrm{C}$ ) e dois tipos de substrato (sobre papel e entre papel), na presença de luz. Também foram avaliados os tratamentos prégerminativos: imersão em água (24 horas); imersão em solução de hipoclorito a 6\% (1 hora); imersão em solução de nitrato de potássio a $0,2 \%$ (24 horas); imersão em solução de giberelina 0,05\% (24 horas) e testemunha (sementes sem tratamento prévio). A maior porcentagem de germinação foi verificada na temperatura alternada $20-30{ }^{\circ} \mathrm{C}$, e não houve diferença significativa
\end{abstract}

${ }^{1}$ Submitted on 25/02/2010. Accepted for publication on 22/08/2010.Part
of Doctoral Thesis of First Author. ${ }^{2}$ Post-Doctoral student of Post-graduate Program of Department of Plant Sciences, UFV-Viçosa - MG; e-mail: beatriz.brasileiro@ufv.br

${ }^{3}$ Associate Professor of Department of Plant Sciences of Federal University of Viçosa-UFV-Viçosa-MG; email: dcdias@ufv.br
${ }^{4}$ Full Professor of Department of Plant Sciences of Federal University of Viçosa - UFV,- Viçosa - MG; e-mail: casali@ufv.br

${ }^{5}$ Researcher, MS, Department of Plant Sciences, UFV-Viçosa - MG; e-mail: mbhering@ufv.br

${ }^{6}$ Associate Professor of the Department of Computer Science of Federal University of Viçosa- UFV- Viçosa- MG; email:cecon@ufv.br 
entre os substratos nesta temperatura. A imersão das sementes em $\mathrm{KNO}_{3}$ proporcionou as melhores respostas de porcentagem e índice de velocidade de germinação (IVG), diferindo dos outros tratamentos, a exceção do tratamento de imersão em água. A pré-embebição das sementes de $T$. triangulare favorece o processo germinativo e pode ser realizado apenas em água pura propiciando germinação mais rápida e uniforme.

Termos para indexação: substrato, germinação, dormência, planta medicinal.

\section{INTRODUCTION}

The medicinal, economic and ecological importance of native Brazilian species and the risk of extinction by man's predatory actions, have motivated studies on the preservation and rational use of these species.

Talinum triangulare (Jacq.) Willd is used in food (Fasuyi, 2007) and in traditional medicine (Agra et al., 2008). This species reproduces by seed and its principal dissemination strategies are wind dispersal and a large seed production. The seeds are produced in yellow capsules, measuring 5-7 $\mathrm{mm}$, which burst when ripe, dispersing the many seeds, which are small, and brownish-red when immature and black when ripe (Figure 1A-B) (Kissmann and Groth, 1999). Dormancy is probably another survival strategy since some authors admit that $T$. triangulare seeds can show dormancy due to the tegument, which is presumably impermeable to water and/ or gases (Fawusi, 1979).
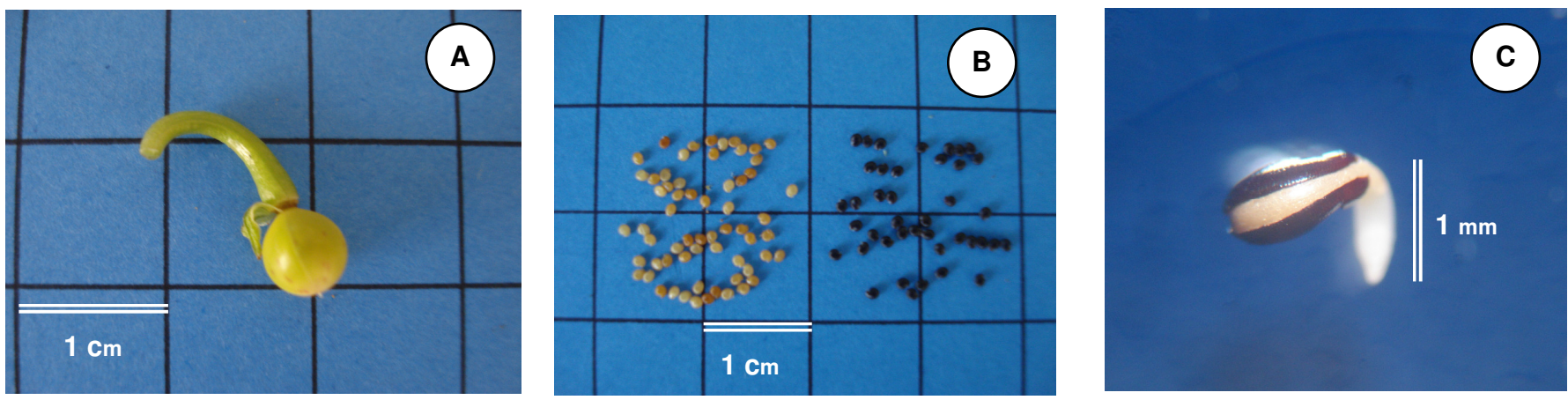

FIGURE 1. Talinum triangulare (Jacq.) Willd.: A - Ripe fruit; B - Seeds. C - Protrusion of primary root.

Various factors affect the seed dormancy level of wild species. These types of study have been done principally with temperate climate species and have shown that the main stimulants are: light (Om et al., 2003), alternate temperatures (Ikeda et al., 2008; Ferreira e Rosa, 2009) and potassium nitrate (Chauhan et al., 2006).

The optimum temperatures for the germination of most tropical species lie between 20 and $30{ }^{\circ} \mathrm{C}$ and the maximum between 35 and $40{ }^{\circ} \mathrm{C}$. Other factors interfere in seed germination besides temperature, especially the hormonal equilibrium of the embryo and tegument permeability. These factors can retard the beginning of the germination process of those seeds which remain longer in the soil and which are responsible for maintaining the seed bank. However, this may be a problem when the objective is seedling propagation and production. (Marcos Filho, 2005).

Some treatments may be used to stimulate, accelerate or standardize the germination of dormant or immature seeds. The treatments commonly used consist of immersing seeds in water at room temperature, hot or boiling, for different periods; immersion in various concentrations of gibberellic acid, associated or not with citocinin; using $\mathrm{KNO}_{3}$ solutions and mechanical or chemical scarification (Brasil, 2009). Gibberellin was successfully used for the germination of medicinal species, such as Egletes viscosa (Bezerra et al., 2006) and Smilax japicanga Griseb (Santos et al., 2003). 
The immersion of seeds in chemical products, such as sodium hypochlorite, potassium nitrate and hydrogen peroxide is a common practice to stimulate germination. Studies by Meireles (2007) showed that the pre-imbibition of coffee seeds for 6 hours in an aqueous solution of sodium hypochlorite, containing $5 \%$ of active chlorine, degraded the parchment without damaging the embryo, resulting in a percentage germination and germination speed similar to the manual removal of the parchment.

The more adequate conditions for seed germination of the most wild plant species, including $T$. triangulare, are still poorly known, which makes a study of techniques to accelerate and standardize germination necessary. Therefore, the objective of this study was to evaluate the effects of temperature and pre-germinative treatments on the percentage and speed of germination of $T$. triangulare seeds.

\section{MATERIALS AND METHODS}

The experiments were carried out at the Seed Research Laboratory of the Department of Plant Science, at Federal University of Viçosa. The seeds were collected in May 2009 from plants propagated from seeds and cultivated in green houses with $30 \%$ shade mesh and a transparent plastic polyethlene film.

Initially, the weight of 1,000 seeds and the seed moisture content were determined according to Rules for Seed Testing (Brasil, 2009).

The curve for seed imbibition in water was determined to evaluate the presence of tegument dormancy. The seeds were placed in a gerbox with previously moistened towel paper (2.5 times its weight), with the water content being re-established every $24 \mathrm{~h}(1.0$ $\mathrm{mL}$ per gerbox). During the evaluations, which occurred after $3,6,9,12,24,36,48,60$ and $72 \mathrm{~h}$ of imbibition, the seeds were removed from the gerbox and carefully dried with a paper towel, weighed on a digital balance with a precision of $0.001 \mathrm{~g}$ and placed once more in the gerbox to continue imbibition. From the values of the consecutive weightings the mean percentage of water gain in relation to the initial seed weight was calculated and the imbibition curve plotted.

Evaluation of the effects of temperature and substrates on germination: germination tests were done according to a completely randomized experimental design, in a $4 \times 2$ factorial scheme, with four temperatures (constant of $20,25,30{ }^{\circ} \mathrm{C}$ and alternate of $20-30{ }^{\circ} \mathrm{C}$ ) and two types of seeding: on paper (seeds without any covering) and between paper (seeds covered with a sheet of germitest paper), with a $12 \mathrm{~h}$ photoperiod. Four replications of 100 seeds were used, distributed on two sheets of towel paper, moistened with distilled water (2.5 times own weight) in transparent plastic boxes. The accumulated germination, final germination and germination speed index were determined (Maguire, 1962). A seed was considered as germinated after emitting the primary root (Labouriau, 1983). A count of the number of seeds with a root length of at least $1.0 \mathrm{~mm}$ was made every two days to calculate the germination speed index (Fig. 1C), over 30 days. The data were interpreted by an analysis of variance and the means compared by the Tukey test $(\mathrm{P}<0.05)$.

Evaluation of the effects of pre-germinative treatments: germination tests were done using a completely randomized experimental design, with four repetitions of 100 seeds and five treatments: immersion in water $(24 \mathrm{~h})$; immersion in $6 \%$ hypochlorite solution $(1 \mathrm{~h})$; immersion in $0.2 \%$ potassium nitrate solution ( 24 h); immersion in $0.05 \%$ gibberellin solution and the control (untreated seeds). The imbibition treatments were performed at room temperature $\left( \pm 25^{\circ} \mathrm{C}\right)$. The standard germination test follows the same methodology described in the previous trial, using alternate temperatures of 20-30 ${ }^{\circ} \mathrm{C}$. Germination was evaluated daily over 15 days using the same criterion as the previous trial. The following variables were analyzed: accumulated germination, final germination and the germination speed index (Maguire, 1962). The data were interpreted by an analysis of variance and the means compared by the Tukey test $(\mathrm{P}<0.05)$.

\section{RESULTS AND DISCUSSION}

The water content and weight of 1,000 seeds were $9.64 \%$ and $0.315 \mathrm{~g}$ respectively. The imbibition curve for seeds in water (Figure 2) shows that the tegument did not prevent water absortion by the seeds. These results differ from those of Fawusi (1979) who, working with seeds harvested in Africa, concluded that there was dormancy in $T$. triangulare due to the hardness of the tegument and emphasized the partial removal of the tegument as the most efficient method to overcome this. This difference may be associated with environmental and genetic differences of the study populations because the impermeability of the tegument to water is a hereditary character and significantly influenced by the environment (Marcos Filho, 2005). 


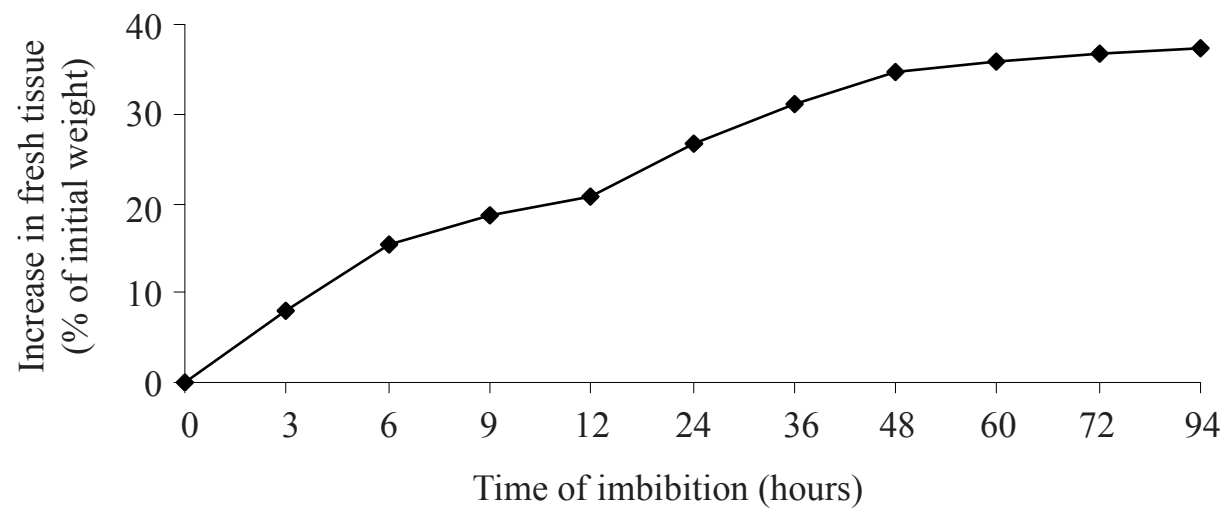

FIGURE 2. Curve of imbibition in water by Talinum triangulare (Jacq.) Willd. seeds.

Effect of the temperature and substrate on germination: the germination percentage $(\mathrm{G})$ and the germination speed index (GSI) were significantly affected $(\mathrm{P} \leq 0.01)$ by the temperature and the substrate. The highest percentage of germination was seen at the alternate temperatures of $20-30{ }^{\circ} \mathrm{C}$, but there were no differences between substrates at this temperature (Table 1). The greatest reductions in germination and germination speed occurred at $25^{\circ} \mathrm{C}$ and $30^{\circ} \mathrm{C}$. The demand for alternating temperatures in the seed germination of various species implies that a large proportion of thent will remain dormant in the soil if the daily variation is small (such as in shady environments), but will germinate in open and sunny sites, or when light manages to penetrate (Borghetti, 2000).

TABLE 1. Germination percentage and germination speed index (GSI) of Talinum triangulare seeds as a function of temperature and substrate.

\begin{tabular}{lcrrr}
\hline \multirow{2}{*}{ Temperature $\left({ }^{\circ} \mathrm{C}\right)$} & \multicolumn{2}{c}{ Germination $(\%)$} & GSI \\
\cline { 2 - 5 } & \multicolumn{1}{c}{ On paper } & Between paper & On paper & Between paper \\
\hline 20 & $54.00 \mathrm{a} \mathrm{B}$ & $25.25 \mathrm{~b} \mathrm{~B}$ & $4.62 \mathrm{a} \mathrm{B}$ & $1.40 \mathrm{~b} \mathrm{~B}$ \\
25 & $9.75 \mathrm{a} \mathrm{C}$ & $11.75 \mathrm{a} \mathrm{C}$ & 0.51 a C & $0.70 \mathrm{a} \mathrm{C}$ \\
30 & $2.25 \mathrm{a} \mathrm{D}$ & 3.75 a D & 0.17 a C & 0.24 a C \\
$20-30$ & $95.75 \mathrm{a} \mathrm{A}$ & $95.50 \mathrm{a} \mathrm{A}$ & 12.05 a A & $11.13 \mathrm{~b} \mathrm{~A}$ \\
\hline
\end{tabular}

Means followed by the same small letter in the line or capital letter in the column for each characteristic are not significantly different by the Tukey test $(\mathrm{P}>0.05)$.

Many wild species need a daily temperature fluctuation to germinate (Silva et al., 2002), considering that alternating temperatures correspond to the adaptation of species to natural environmental fluctuations (Steckel et al., 2004). Thus, seeds from wild species, such as $T$. triangulare, tend to repeat their behavior in the natural environment in the laboratory where the temperatures vary between day and night and constant temperatures rarely occur. Carvalho and Christoffolet (2007) studied the germination of five Amaranthus species and concluded that alternate temperatures of $20-30{ }^{\circ} \mathrm{C}$ were the most suitable for germination. Other authors also verified that alternate temperatures promote germination of seeds of Aloysia gratissima and Psychotria leicocarpa (Rosa and Ferreira, 2001), Borreria verticillata and Cayaponia martiana (Ferreira and Rosa, 2009), Eclipta alba and Tagetes minuta (Ferreira et al., 2001), Ageratum conyzoides (Ikeda et al., 2008), and Pyrostegia venusta 
(Scalon et al., 2008).

The germination speed index accompanies total germination, i.e., germination speed was also significantly higher at the alternatetemperatures of $20-30{ }^{\circ} \mathrm{C}$. According to Borghetti and Ferreira (2004), the fact that a large part of the seeds germinates uniformly in a short space of time, implies that germination is not random but responding to some biochemical or metabolic germination control mechanism, the temperature in this case, resulting in a synchronization of the process.

In the evaluation of the substrates, the only difference observed was for germination at $20{ }^{\circ} \mathrm{C}$. However, for the germination speed index, there was a difference between substrates at the constant $20{ }^{\circ} \mathrm{C}$ temperature or the alternate temperatures $20-30{ }^{\circ} \mathrm{C}$ (Table 1 ).

According to the accumulated germination curves (Figure 3), germination of $T$. triangulare tends to remain constant from the 10th day after sowing, both on paper or between papers, at the $20-30{ }^{\circ} \mathrm{C}$ temperatures. This shows that at the alternating temperatures of $20-30{ }^{\circ} \mathrm{C}$, the germination test of $T$. triangulare seeds can be stopped earlier without having to wait 30 days.
Between paper

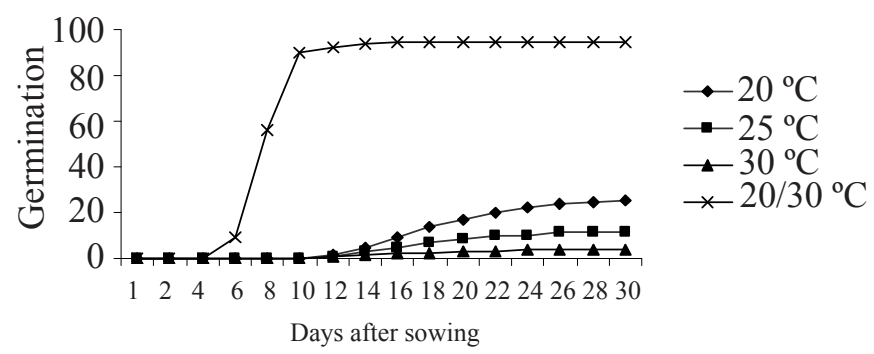

On paper

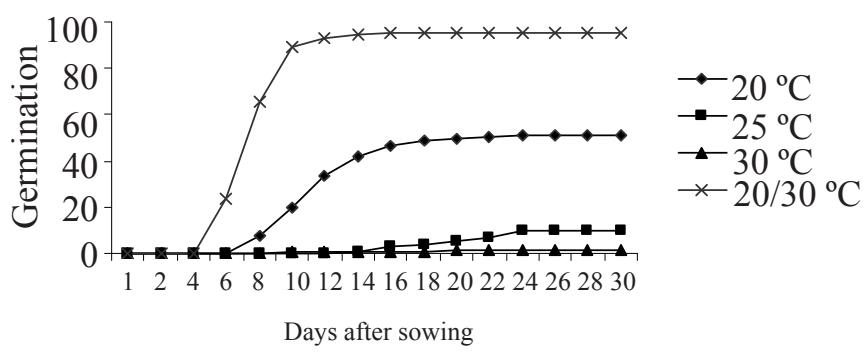

FIGURE 3. Accumulated germination of Talinum triangulare (Jacq.) Willd. seeds at four temperatures.

Effect of pre-germinative treatments: there was a significant treatment effect $(\mathrm{P} \leq 0.01)$ on percentage germination $(\mathrm{G})$ and germination speed index (GVI) of T. triangulare seeds. The immersion of seeds in $\mathrm{KNO}_{3}$ gave the best responses in percentages and germination speed index (GSI), differing significantly from the other treatments, except for the immersion in water treatment (Table 2). Hilhorst (1990), studying Sisymbrium officinale, concluded that nitrate could function as a co-factor in the action of phytochrome, suggesting that optimum quantities of nitrate can generate more active phytochrome receptors and/ or inhibit the inactivation of these receptors. For T. triangulare seeds, the $\mathrm{KNO}_{3}$ solution did not substitute the light effect since the trial was not done in the dark. On the other hand, since germination was high and the germination speed index greater for seeds treated with this chemical, with light, an increase in the number of active phytochrome receptors may have occurred, thus triggering the germination process more easily.
TABLE 2. Germination percentage and germination speed index (GSI) of Talinum triangulare seeds submitted to five pre-germinative treatments at alternate temperatures of 20-30 ${ }^{\circ} \mathrm{C}$.

\begin{tabular}{lcr}
\hline \multicolumn{1}{c}{ Treatment } & Germination (\%) & \multicolumn{1}{c}{ GSI } \\
\hline Immersion in $\mathrm{KNO}_{3}$ & $78.75 \mathrm{a}$ & $10.82 \mathrm{a}$ \\
Immersion in water & $67.00 \mathrm{ab}$ & $8.53 \mathrm{~b}$ \\
Immersion in gibberellin & $62.00 \mathrm{~b}$ & $7.85 \mathrm{~b}$ \\
Control & $59.25 \mathrm{~b}$ & $6.86 \mathrm{~b}$ \\
Immersion in hypochlorite & $1.50 \mathrm{c}$ & $0.17 \mathrm{c}$ \\
\hline
\end{tabular}

In each column, means followed by the same letter are not significantly different by the

Tukey test $(\mathrm{P}>0.05)$.

Ikeda et al. (2008) observed that the moistening of the substrate with $\mathrm{KNO}_{3}$ in the presence of light and alternating temperatures $\left(15-35^{\circ} \mathrm{C}\right)$ resulted in increases 
in the percentage and speed of germination of Ageratum conyzoides. Scalon et al. (2008) also studied the effect of pre-germinative treatments in Pyrostegia venusta, a medicinal species, and concluded that immersion of the seeds in $\mathrm{KNO}_{3}$ resulted in higher germination and more fresh seedling tissue.

The application of $\mathrm{KNO}_{3}$ can result in significantly different responses between species. In Hypericum brasiliense, the moistening of the substrate with an aqueous solution of $0.2 \% \mathrm{KNO}_{3}$ increased germination, whereas in Hypericum perforatum this treatment caused no significant effect (Faron et al., 2004).

The immersion of seeds in hypochlorite was harmful, inhibiting germination almost totally. Observations of germination inhibition by hypochlorite indicate that certain seeds, whose tegument are not a physical barrier to germination, can be scarified to the point where live tissues are damaged (Carnelossi et al., 1995), which may possibly have occurred with the Talinum triangulare seeds.

Shuying et al. (2003) showed that previous imbibition of $T$. triangulare seeds for three hours at $25{ }^{\circ} \mathrm{C}$, and a germination temperature of $35^{\circ} \mathrm{C}$, increased the percentage of seed germination, and this was also observed in the present study. The beneficial effect of immersing seeds in water, which favored germination, was also seen in Astrocaryum aculeatum, when the percentage germination progressively increased as the imbibition period of the seeds in water increased, reaching $70 \%$ after nine days of imbibition (Ferreira e Gentil, 2006). The pre-imbibition of the seeds in water for 24 and $48 \mathrm{~h}$ increased the percentage and speed of germination and reduced the mean germination time of Egletes viscose (Bezerra et al., 2006) and Magonia pubescente (Macedo et al., 2009).

Under natural conditions, many factors influence the initiation and continuity of germination and, therefore, seeds of the same species can germinate after very different periods, depending on external conditions. Considering the results found under the conditions of the present study, it can be verified that $T$. triangulare seeds do not show tegument dormancy and their germination is favored by alternate temperatures and pre-imbibition in water.

\section{CONCLUSIONS}

The alternate temperatures of $20-30{ }^{\circ} \mathrm{C}$ are beneficial for the germination of $T$. triangular seeds. The preimbibition of seeds favors a rapid and uniform germination and may be done by simply using pure water without the addition of any other chemical product.

\section{REFERENCES}

AGRA, M.F.; SILVA, K.N.; BASÍLIO, I.J.L.D.; FRANÇA, P.F.; BARBOSA-FILHO, J.M. Survey of medicinal plants used in the region Northeast of Brazil. Revista Brasileira de Farmacognosia, v.18, p.472-508, 2008.

BEZERRA, A.M.; MEDEIROS FILHO, S.; BRUNO, R.L.A.; MOMENTÉ, V.G. Efeito da pré-embebição e aplicação de ácido giberélico na germinação de sementes de macela. Revista Brasileira Sementes, v.28, n.3, p.185190, 2006.

BRASIL. Ministério da Agricultura, Pecuária e Abastecimento. Regras para análise de sementes. Ministério da Agricultura, Pecuária e Abastecimento. Secretaria de Defesa Agropecuária. Brasília, DF: Mapa/ ACS, 2009. 399p.

BORGHETTI, F. Ecofisiologia da germinação das sementes. Universia, v.8, p.149-179, 2000.

BORGHETTI, F.; FERREIRA, A.G. Interpretação de resultados de germinação. In: FERREIRA, A.G.; BORGHETTI, F. (Orgs.). Germinação: do básico ao aplicado. São Paulo: Artmed, 2004. 323p.

CARNELOSSI, M.A.G.; LAMOUNIER, L.; RANAL, M.A. Efeito da luz, hipoclorito de sódio, escarificação e estratificação na germinação de sementes de alface (Lactuca sativa L.), cv. Maioba, e Moreninha-de-Uberlândia. Pesquisa Agropecuária Brasileira, v.30, n.6, p.779-787, 1995.

CARVALHO, S.J.P.; CHRISTOFFOLETI, P.J. Influência da luz e da temperatura na germinação de cinco espécies de plantas daninhas do gênero Amaranthus. Bragantia, v.66, n. 4, p. 527-533, 2007.

CHAUHAN, B.S.; GILL, G.; PRESTON, C. Factors affecting seed germination of threehorn bedstraw (Galium tricornutum) in Australia. Weed Science, v.54, p.471-477, 2006.

FARON, M.L.B; PERECINI, M.B.; LAGO, A.A; BOVI, O.A; MAIA, N.B. Temperatura, nitrato de potássio e fotoperíodo na germinação de sementes de Hypericum perforatum L. e H. brasiliense Choisy. Bragantia, v.63, n.2, p.193-199, 2004.

FASUYI, A.O. Bio-nutritional evaluations of three tropical leaf vegetables Telfairia occidentalis, Amaranthus cruentus and Talinum triangulare as sole dietary protein sources in rat assay. Food Chemistry, v.103, n.3, p.757-765, 2007. 
FAWUSI, M.O.A. Germination of Talinum triangulare L. seeds as affected by various chemical and physical treatments. Annals of Botany, v.44, p.617-622, 1979.

FERREIRA, A.G.; ROSA, S.G.T. Germinação de sementes de sete espécies medicinais nativas do sul do Brasil. Revista Brasileira de Plantas Medicinais, v.11, n.3, p.230-235, 2009.

FERREIRA, A.G.; CASSOL, B.; DA ROSA, S.G.T.; SILVEIRA, T.S.; STIVAL, A.L.; SILVA, A.A. Germinação de sementes de Asteraceae nativas no Rio Grande do Sul, Brasil. Acta Botânica Brasílica, v.15, n.2, p.231-242, 2001.

FERREIRA, S.A.N.; GENTIL, D.F.O. Extração, embebição e germinação de sementes de tucumã (Astrocaryum aculeatum). Acta Amazônica, v.36, n.2, p.141-146, 2006.

HILHORST, H.W.M. Dose-response analysis of factors involved in germination and secondary dormancy of seeds of Sisymbrium officinale. II. Nitrate. Plant Physiology, v.94, p.1096-1102, 1990.

IKEDA, F.S.; CARMONA, R.; MITJA, D.; GUIMARAES, R.M. Luz e $\mathrm{KNO}_{3}$ na germinação de sementes de Ageratum conyzoides L. sob temperaturas constantes e alternadas. Revista Brasileira de Sementes, v.30, n.2, p.193-199. 2008.

KISSMANN, K.G.; GROTH, D. Plantas infestantes e nocivas. São Paulo: Basf Brasileira, 1999. v.2, 798p.

LABOURIAU, L.G. A germinação das sementes. Washington, D.C.: Organização dos Estados Americanos, Programa Regional de Desenvolvimento Científico e Tecnológico, 1983. 174p. (Série de Biologia. Monografia, 24).

MACEDO, M.C.; SCALON, S.P.Q.; SARI, A.P.; ROSA, Y.S.C.J.; ROBAINA, A.D. Biometria de frutos e sementes e germinação de Magonia pubescens ST.Hil (Sapindaceae). Revista Brasileira de Sementes, v.31, n.2, p.202-211, 2009.
MAGUIRE, J.D. Speed of germination: aid and selection and evaluation for seedling emergence and vigor. Crop Science, v.2, n.2, p.176-177, 1962.

MARCOS FILHO, J. Fisiologia das sementes de plantas cultivadas. FEALQ: Piracicaba: 2005. 495 p.

MEIRELES, R.C.; ARAUJO, E.F.; REIS, M.S.; SEDIYAMA, C.S.; SAKIYAMA, N.S.; REIS, L.S. SECAFÉ: Metodologia para acelerar a germinação das sementes de café. Revista Brasileira de Sementes, v.29, p.90-96, 2007.

OM, H.; KUMAR, S.; DHIMAN, S.D. Dormancy and viability of Phalaris minor seed in a rice-wheat cropping system. Weed Research, v.45, p.140-148, 2003.

ROSA, S.G.T.; FERREIRA, A.G. Germinação de sementes de plantas medicinais lenhosas. Acta Botânica Brasílica, v.15, p.147-154, 2001.

SANTOS, M.R.A.; PAIVA, R.; GOMES, G.A.C.; PAIVA, L.V. Estudos sobre superação de dormência em sementes de Smilax japecanga Grisebach. Ciência e Agrotecnologia, v.27, n.2, p.319-324, 2003.

SCALON, S.P.Q.; VIEIRA, M.C.; LIMA, A.A.; SOUZA, C.M.; MUSSURY, R.M. Tratamentos pré-germinativos e temperaturas de incubação na germinação de cipóde-São-João (Pyrostegia venusta (Ker Gawl.) Miers) Bignoniaceae. Revista Brasileira de Plantas Medicinais, v.10, n.4, p.37-42, 2008.

SHUYING, F.; CAIJUN, W.; HONGHAI, C.; BIJUN, Y. A study on germination of Talinum triangulare (Jacq.) Willd. Acta Agriculturae Universitatis Jiangxiensis. v.25, n.3, p.356-358, 2003.

SILVA, L.M.M.; RODRIGUES, T.J.D.; AGUIAR, E.B. Efeito da luz e a temperatura na germinação de sementes de aroeira (Myracrodruon urundeuva). Revista Árvore, v.26, p.691-697, 2002.

STECKEL, L.E.; SPRAGUE, C.L.; STOLLER, E.W.; WAX, L.M. Temperature effects on germination of nine Amaranthus species. Weed Science, v.52, n.2, p.217-221, 2004. 